\title{
Features of the immunoreactivity T and B lymphocytes subpopulations and cytokine imbalance in patients with hepatosplenomegaly of different etiology
}

\author{
0. M. Klimova ${ }^{\mathbb{D}} * 1,2, A, D, E$, T. I. Kordon ${ }^{1, A-E}$, S. V. Sushkov ${ }^{1, B, C, F}$, L. A. Drozdova ${ }^{1, B, C, D, F}$, \\ 0. V. Lavinska ${ }^{1,2, B-E}$, 0. S. Merezhko ${ }^{1,2, B, C, D}$, K. O. Bychenko ${ }^{1,2, B, C, D}$
}

${ }^{1}$ State Institution "Zaitsev V. T. Institute of General and Urgent Surgery of National Academy of Medical Sciences of Ukraine", Kharkiv, ${ }^{2}$ V. N. Karazin Kharkiv National University

A - research concept and design; B - collection and/or assembly of data; C - data analysis and interpretation; D - writing the article; $\mathrm{E}$ - critical revision of the article; $\mathrm{F}$ - final approval of the article

Key words: hepatosplenomegaly, trigger factor, immunoreactivity, cytokines, lymphocyte subpopulations, B lymphocytes, T lymphocytes.

Pathologia 2021; 18 (2), 174-182

*E-mail: klimovalena53@ gmail.com
The aim was to study the mechanisms of immunological dysregulation of cytokine and immunoglobulin production, changes in the $\mathrm{CD}$ expression of $\mathrm{T}$ and $\mathrm{B}$ lymphocyte subpopulations in patients with hepatosplenomegaly of different etiology.

Materials and methods. We examined 73 patients with liver cirrhosis complicated by portal hypertension, hepatosplenomegaly, and bleeding from phlebectasia. We identified three groups of patients depending on the triggering factors of cirrhosis: the first (I) group - HBV/HCV; the second (II) group - CMV/VEB; the third (III) group - hereditary enzymopathies. The study material was lymphocytes and blood serum. We used the methods of ELISA, immunofluorescence and flow cytometry.

Results. An increase in the concentration of $\lg A$ and $\operatorname{lgM}$ was revealed against the background of normal number of $C D 22^{+}$ B lymphocytes with HBV/HCV (I group), high level of IgM and their producers, B lymphocytes, with CMV/VEB (II group), in group III with hereditary enzymopathies, the concentration of all immunoglobulins was normal with an increased content of $B$ lymphocytes. Multidirectional changes in the content of cytokines were revealed: in group I the synthesis of anti-inflammatory cytokines IL-4, IL-10 and in group II - pro-inflammatory IL-1 $\beta$, INF- $\gamma$, TNF- $\alpha$ dominated; in group III the concentration of IL-6 and vascular growth factor (VEGF) was maximally increased. The number of activated $\mathrm{CD} 3^{+} \mathrm{CD} 4^{+} \mathrm{CD} 25^{+} \mathrm{T}$ cells was reduced in groups I and II - by 2.3 and 2.0 times respectively, in group III - increased by 1.2 times. The number of regulatory $\mathrm{T}$ lymphocytes $\mathrm{CD} 3^{+} \mathrm{CD} 4^{+} \mathrm{CD} 25^{+} \mathrm{CD} 127^{\text {neg }}$ was reduced by half in I and II groups. Expression of co-stimulatory molecules $\mathrm{CD}^{+} \mathrm{CD} 4^{+} \mathrm{CD} 28^{+}$was low in all groups and the maximum decrease was in group III. In patients with $\mathrm{HCV} / \mathrm{HBV}$, an increase in the expression of the late activation marker of lymphocytes $C D 3^{+} H L A-D R^{+}$by an average of $63 \%$ was noted.

Conclusions. The revealed immune disorders in hepatosplenomegaly of different etiology are characterized by multidirectional changes. Approaches to the treatment of these patients should be complex, taking into account the trigger factors that cause dysregulation of immune responses, which leads to further destruction, and focuses at remodeling target organs.
Киючові слова: гепатоспиеномегалія, тригерний фактор, імунореактивність, цитокіни, субпопуляція мімфоцитів, В-мімфоцити, Т-мімфоцити.

Патологія. 2021. T. 18, № 2(52). C. 174-182

\section{Особливості імунореактивності субпопуляцій Т- і В-лімфоцитів і цитокіновий дисбаланс у пацієнтів із гепатоспленомегалією різної етіології}

\author{
О. М. Киімова, Т. І. Кордон, С. В. Сушков, А. А. Ароздова, О. В. Аавінська, \\ О. С. Мережко, К. О. Биченко
}

Мета роботи - вивчення механізмів імунологічної дисрегуляції продукції цитокінів, імуноглобулінів та зміни експресії кластерів диференціювання CD субпопуляцій T- і В-лімфоцитів у хворих на гепатоспленомегалію різної етіології.

Матеріали та методи. Матеріал для дослідження - лімфоцити та сироватка крові 73 пацієнтів із гепатоспленомегалією на тлі цирозу печінки, що ускладнений портальною гіпертензією та кровотечами з фрлебектазій. Хворих поділили на 3 групи залежно від етіології: I -інфіковані вірусами гепатиту HBV/HCV; II -інфіковані вірусами герпесу CMVNEB; III -зі спадковими ферментопатіями. Використовували методи імуноферментного аналізу, імунофрлуоресценції, проточної цитофруориметрії.

Результати. У пацієнтів із різними етіологічними фракторами гепатоспленомегалії виявили підвищення концентрації IgA та IgM на тлі нормальної кількості CD22+-B-лімфоцитів при інфікуванні вірусами HBV/HCV (група I), високий рівень IgM та їхніх продуцентів, В-лімфоцитів, при інфікуванні вірусами CMVNEB (група II), III (зі спадковими ферментопатіями) концентрація всіх класів імуноглобулінів відповідала нормі при підвищеному вмісті В-лімфоцитів. Виявили різноспрямовані зміни вмісту цитокінів: у групі I домінував синтез протизапальних цитокінів ІЛ-4, IЛ-10, у групі II - прозапальних IЛ-1 $1 \beta$, IHФ-ү, ФНП-а; у групі III максимально підвищена концентрація IЛ-6 і фактора росту судин - VEGF. Кількість активованих CD3 ${ }^{+}$CD4 $4^{+}$CD25+ T-клітин знижена в пацієнтів I та II груп у 2,3 i 2,0 раза відповідно, а у групі III збільшена в 1,2 раза. Кількість регуляторних Т-лімфоцитів $\mathrm{CD} 3^{+} \mathrm{CD} 4^{+} \mathrm{CD} 25^{+} \mathrm{CD} 127^{\text {neg }}$ знижена вдвічі в I i II групах. Експресія костимулювальних молекул $\mathrm{CD}^{+} \mathrm{CD} 4^{+} \mathrm{CD} 28^{+}$низька в усіх групах обстежених, максимальне зниження виявили у III групі. У пацієнтів на тлі вірусів HCV/HBV визначили збільшення експресії маркера пізньої активації лімфоцитів CD3+HLA-DR+ в середньому на $63 \%$.

Висновки. Імунні порушення при гепатоспленомегалії різної етіології характеризуються різноспрямованими змінами. Підходи до лікування пацієнтів з гепатоспленомегалією повинні бути комплексними, враховувати тригерні фрактори, які викликають дисрегуляцію імунних реакцій, що надалі призводить до деструкції, і спрямовані на ремоделювання органів-мішеней. 


\title{
Особенности иммунореактивности субпопуляций Т- и В-лимфоцитов и цитокиновый дисбаланс у пациентов с гепатоспленомегалией различной этиологии
}

\author{
Е. М. Климова, Т. И. Кордон, С. В. Сушков, А. А. Ароздова, Е. В. Аавинская, \\ О. С. Мережко, Е. А. Быченко
}

Цель работы - изучение механизмов иммунологической дисрегуляции продукции цитокинов, иммуноглобулинов и изменения экспрессии кластеров дифференцировки CD субпопуляций T- и B-лимфоцитов у больных гепатоспленомегалией различной этиологии.

Материалы и методы. Материал для исследования - лимфоциты и сыворотка крови 73 пациентов с гепатоспленомегалией на фоне цирроза печени, осложненного портальной гипертензией и кровотечениями из флебэктазий. Больных поделили на 3 группы в зависимости от этиологии: I - инсицированные вирусами гепатита HBV/HCV; II инфицированные вирусами герпеса CMVIVEB; III - с наследственными ферментопатиями. Использовали методы иммуноферментного анализа, иммунофлуоресценции, проточной цитофрлуориметрии.

Результаты. У пациентов с различными этиологическими фракторами гепатоспленомегалии установили повышение концентрации IgA и IgM на фоне нормального количества CD22+-B-лимфоцитов при инфицировании вирусами HBV/ HCV (группа I), высокий уровень IgM и их продуцентов, В-лимфоцитов, при инфицировании вирусами CMVNEB (группа II), в группе III с наследственными ферментопатиями концентрация всех классов иммуноглобулинов была в норме при повышенном содержании В-лимфоцитов. Отмечены разнонаправленные изменения содержания цитокинов: в группе I доминировал синтез противовоспалительных цитокинов ИЛ-4, ИЛ-10, в группе II - провоспалительных ИЛ-1 $\beta$, ИНФ-ү, ФНО-а; в группе III - максимально повышена концентрация ИЛ-6 и фактора роста сосудов - VEGF. Количество активированных CD3 ${ }^{+} \mathrm{CD} 4^{+} \mathrm{CD} 25^{+}$T-клеток снижено у пациентов I и II групп - в 2,3 и 2,0 раза соответственно, а в группе III увеличено в 1,2 раза. Количество регуляторных Т-лимфоцитов $C D 3^{+} C D 4^{+} C D 25^{+} C D 127^{\text {eg }}$ снижено вдвое в I и II группах. Экспрессия костимулирующих молекул $\mathrm{CD} 3^{+} \mathrm{CD} 4^{+} \mathrm{CD} 28^{+}$была низкой во всех группах обследованных, максимальное снижение отмечено в III группе. У пациентов на фроне вирусов HCV/HBV установлено увеличение экспрессии маркера поздней активации лимфоцитов $C D 3^{+} \mathrm{HLA}^{-} \mathrm{DR}^{+}$в среднем на $63 \%$.

Выводы. Иммунные нарушения при гепатоспленомегалии различной этиологии характеризуются разнонаправленными изменениями. Подходы к лечению пациентов с гепатоспленомегалией должны быть комплексными, учитывать триггерные факторы, вызывающие дисрегуляцию иммунных реакций, что приводит к дальнейшей деструкции, и направлены на ремоделирование органов-мишеней.

Hepatosplenomegaly is manifested by an increase in the liver and spleen size, occurs often in viral hepatitis, cholestasis, biliary cirrhosis and hereditarily determined storage diseases. Structural and functional disorders of the spleen are caused by pathological changes in the mechanisms of cellular filtration of blood, antigen elimination, hematopoiesis and deposition of blood cells $[1,2]$.

The entry of infectious antigens and cellular debris through the portal vein into the liver from the digestive tract leads to an immediate response of the liver immune cells macrophages of the reticuloendothelial system, which are the first line of defense against foreign antigens [3].

Filtration of blood in the spleen and liver ensures the toxic factors elimination and infectious antigens that activate the toll-like receptor 4 (TLR-4) of immunocompetent cells and the expression of cluster of differentiation 14 (CD14) on Kupffer cells. Subsequently, the transcription of cytokine genes (IL-1 and TNF- $\alpha$ ) is triggered, and the entire cascade of immunological reactions is turned on $[4,5]$. Disturbance function of immune cells is the main pathogenetic factor of the hepatobiliary zone diseases.

There is a pronounced clinical heterogeneity in the course of the disease in patients with hepatosplenomegaly. At the same time, the molecular and cellular mechanisms of metabolic disorders and their reversibility degree are not fully understood. Progressive damage of the liver and spleen can be associated with various trigger factors, such as the presence of a chronic inflammatory process against the background of infection with various nature antigens with subsequent impairment of immunoreactivity and immunoresistance [6].
The role of the functional viability of the immune system links in patients with various etiological factors of hepatosplenomegaly remains insufficiently studied.

\section{Aim}

The aim of this work was to study the mechanisms of immunological dysregulation of cytokine and immunoglobulin production, changes in the CD expression of $T$ and $B$ lymphocyte subpopulations in patients with hepatosplenomegaly of different etiology.

\section{Materials and methods}

The study was carried out in the Diagnostic Laboratory with Enzyme Immunoassay and Immunofluorescence Analysis of State Institution "Zaitsev V. T. Institute of General and Urgent Surgery of National Academy of Medical Sciences of Ukraine" (registration certificate No. 01-0170/2018).

We examined 73 patients with liver cirrhosis complicated by portal hypertension, hepatosplenomegaly, and bleeding from phlebectasia. These patients were admitted urgently for treatment to the clinic of the SI "Zaitsev V. T. Institute of General and Urgent Surgery of NAMS of Ukraine". We identified three groups of patients depending on the triggering factors of cirrhosis. The first (I) group included 32 patients (20 men and 12 women) with chronic hepatitis $B(\mathrm{HBV})$ or/and $\mathrm{C}(\mathrm{HCV})$ viruses (47\% of the examined) with a mean age of $52.0 \pm 5.6$. The presence of chronic viral hepatitis $B$ was established
Ключевые слова: гепатоспиеномегалия, триггерный фактор, иммунореактивность, цитокины, субпопуляции мимфоцитов, В-лимфоциты, Т-лимфоциты.

Патология. 2021 T. 18, № 2(52).

C. $174-182$ 
on the basis of detecting HBsAg in the blood serum by ELISA. The presence of viral hepatitis $C$ was established on the basis of detecting total anti-HCV antibodies in the blood serum by ELISA.

The second (II) group included 32 patients (17 men and 15 women) with herpes viruses: cytomegalovirus (CMV) and Epstein-Barr virus (EBV) (42\% of the examined) with a mean age of $48.1 \pm 4.7$. The presence of the herpes viruses was established based on the detection of anti-infectious antibodies to CMV and EBV in the blood serum.

The third (III) group included 9 patients (2 men and 7 women) with hereditary enzymopathies, which are a consequence of gene polymorphism of the lysosomal enzymes - glucocerebrosidase (GBA) and chitotriosidase (CHIT1) (11\% of the examined) with a mean age of $37.0 \pm 4.1$.

The mean values of the results of 38 conventionally healthy individuals ( 24 men and 14 women) with a mean age of $45.2 \pm 2.3$ are presented as reference values. They did not have any clinical and laboratory signs of liver and spleen lesions, as well as somatic diseases. The material for the study was lymphocytes and blood serum.

Patients with HIV infection were exclusion criteria from the studies.

The enzyme-linked immunosorbent assay (ELISA) was used for the detection of class-specific serum antibodies ( $\lg \mathrm{A}$, IgM, IgG). We used a kit of reagents "Vector-Best", Novosibirsk. A two-stage sandwich was used with the appropriate monoclonal antibodies (mAbs) $\lg A$, $\operatorname{lgM}, \operatorname{lgG}$. At the first stage, the analyzed samples were incubated with immobilized mAbs. At the second stage, the bound antibodies were treated with a conjugate with peroxidase of mAbs to the light chains of human immunoglobulin. The formed immune complexes were detected by enzymatic reaction with TMB (tetramethylbenzidine). The degree of staining was assessed by measuring the optical density at $\lambda=450 \mathrm{~nm}$ (StatFax 3200, USA), which is proportional to the concentration of immunoglobulin in the sample (in $\mathrm{g} / \mathrm{L}$ ).

Determination of the content of cytokines (IL-1 $\beta, I L-2$, IL-4, IL-6, IL-10, TNF- $\alpha$, INF- $\gamma$ and vascular endothelial growth factor (VEGF)) in blood serum was carried out by the enzyme-linked immunosorbent assay (ELISA) with the appropriate mAbs (kits "Vector-Best", Novosibirsk). At the first stage, the cytokine from the sample was bound with $\mathrm{mAbs}$ immobilized on the inner surface of the wells. Then, after washing, the bound antibodies interact during the second incubation with biotinylated antibodies to human cytokines (conjugate 1). Then, at the third stage, the bound conjugate 1 interacts during incubation with conjugate 2 . Unbound conjugate 2 was removed by washing. The staining of the solution in the wells occurred during incubation with TMB. The optical density at $\lambda=450 \mathrm{~nm}$ (StatFax 3200, USA) was proportional to the concentration of immunoglobulin in the sample (in pg/L).

Expression of clusters of differentiation $\mathrm{CD}_{22}{ }^{+}$was assessed by indirect immunofluorescence using monoclonal antibodies ("Sorbent", RF) labeled with FITC-stain. In this method specific mAbs labeled with FITC not directly, but using a secondary serum, bind to the cell surface antigen. The cells stained by corresponding antibodies were visualized by fluorescent microscopy (Olympus BX53, Japan).

The analysis was performed 2 hours after blood sampling using test tube with the K3 EDTA according to the standard protocol. In each sample at least 5000 cells were analyzed. Various subpopulations of T lymphocytes were determined: $\mathrm{CD}^{+} \mathrm{HLA}-\mathrm{DR}^{+}$(late activation lymphocytes marker), $\mathrm{CD}^{+} \mathrm{CD} 4^{+}$(T helpers), $\mathrm{CD}^{+} \mathrm{CD} 4^{+} \mathrm{CD} 25^{+}$ (activated $\mathrm{T}$ helpers), $\mathrm{CD} 3^{+} \mathrm{CD} 4^{+} \mathrm{CD} 25^{+} \mathrm{CD} 127^{\text {neg }}$ (regulatory $\mathrm{T}$ lymphocytes), $\mathrm{CD} 3^{+} \mathrm{CD} 4^{+} \mathrm{CD} 28^{+}$(co-stimulatory molecules) using appropriate mAbs and dyes: CD3-PC5, CD4-PE, CD28-FITC, CD25-FITC, CD127-Pc7, anti-HLADR-PE (Beckman Coulter, USA). For correct exclusion of cells that did not meet the parameters from the analysis zone, the necessary logical constraints were introduced into the particle distribution histogram for low-angle, side scintillation (SSC). The evaluation of expression level of surface receptors was performed at mean intensity of fluorescence. For the lysis of red blood cells in the samples we used OptiLyse C (Beckman Coulter, USA). The analysis of stained cells was carried out on a flow cytometry Cytomics FC500 (Beckmann Coulter, USA).

To assess the statistical significance of the differences in the groups, the nonparametric Mann-Whitney tests were used. Quantitative data in the tables are presented by the median, as well as the lower (25\%) and upper (75\%) quartiles for each group. The differences were considered significant at $P<0.05$. The results were analyzed using the software package Statistica v.6.

\section{Results}

An evaluation of immunoglobulins in patients with liver cirrhosis complicated by hepatosplenomegaly, portal hypertension and recurrent bleeding showed significant increase IgA (more than 2 times) in group I (patients with hepatitis etiology of hepatosplenomegaly) and by $45 \%$ in group II (patients with herpesvirus etiology of hepatosplenomegaly). An increased lgM content was also revealed - by $53 \%$ in group I, and by $91 \%$ in group II. The IgG content in all studied groups did not differ from the reference values, however, in groups I and II, this indicator was slightly higher than in group III (patients with hereditary enzymopathies) (Table 1).

The concentration of pro-inflammatory IL-1 was reduced by 6 times in group I and increased by 3 times in group II. The content of IL-2 was increased in all studied groups, but maximum increase by 7 times was found in patients with liver cirrhosis against the background of viral hepatitis (group I). The highest increase ( 20 -fold) was IL- 6 among all pro-inflammatory interleukins in all examined groups. The IFN-y level was significantly high in patients with herpesvirus infections (group II) and exceeded the reference values by $75 \%$, while in groups I and III IFN-y did not significantly differ from the reference values. The tumor necrosis factor TNF- $\alpha$ was increased in groups I and II by 4 and 10 times, respectively, while in group III this cytokine was significantly lower than the reference values. The content of anti-inflammatory cytokines IL-4 and IL-10 was increaeesed in all groups. Group I had the greatest increase in IL-4 (6 times) and IL-10 (7 times) relative to the reference values (Table 2). 
Table 1. Serum immunoglobulins concentration in patients with hepatosplenomegaly of different etiology $\left(M e, Q_{25} ; Q_{75}\right)$

\begin{tabular}{|c|c|c|c|c|}
\hline \multirow[t]{2}{*}{ Index, units } & \multirow{2}{*}{$\begin{array}{l}\text { Reference values, } \\
n=38\end{array}$} & \multicolumn{3}{|l|}{ Studied groups } \\
\hline & & Group I (HCV/HBV), $\mathrm{n}=32$ & Group II (CMV/VEB), $\mathrm{n}=32$ & Group III (storage diseases), $n=9$ \\
\hline $\lg A, g / L$ & $1.92(1.23 ; 3.54)$ & $4.12(2.51 ; 6.72)^{\star / * *}$ & $2.76(1.46 ; 4,4)^{\star / * *}$ & $1.91(1.76 ; 2.71)$ \\
\hline $\lg M, g / L$ & $1.20(0.92 ; 1.56)$ & $1.84(1.14 ; 2.56)^{\star \star}$ & $2.30(2.02 ; 3.85)^{\star / * *}$ & $1.31(1.09 ; 1.58)$ \\
\hline $\lg G, g / L$ & $11.55(8.62 ; 14.65)$ & $14.80(11.78 ; 16.50)$ & $14.30(11.60 ; 19.11)$ & $11.80(8.70 ; 14.60)$ \\
\hline
\end{tabular}

*: differences in comparison with the reference values are significant $(P<0.05)$; **: significance of difference between groups I and II $(P<0.05)$.

Table 2. Serum content of pro-inflammatory, anti-inflammatory and regulatory cytokines in patients with hepatosplenomegaly of different etiology (Me, $\left.\mathrm{Q}_{25} ; \mathrm{Q}_{75}\right)$

\begin{tabular}{|c|c|c|c|c|}
\hline \multirow{2}{*}{$\begin{array}{l}\text { Pro-inflammatory, anti-inflam- } \\
\text { matory, regulatory cytokines, units }\end{array}$} & \multirow{2}{*}{$\begin{array}{l}\text { Reference values, } \\
n=38\end{array}$} & \multicolumn{3}{|l|}{ Studied groups } \\
\hline & & Group I (HCV/HBV), $n=32$ & Group II (CMV/VEB), $\mathrm{n}=32$ & Group III (storage diseases), $n=9$ \\
\hline IL-1 $\beta, p g / L$ & $1.6(0.0 ; 2.6)$ & $0.2(0.0 ; 0.4)^{*}$ & $4.3(3.1 ; 5.6)^{* / *}$ & $1.6(0.2 ; 1.9)$ \\
\hline IL-2, pg/L & $0.1(0.0 ; 0.3)$ & $0.8(0.4 ; 0.9)^{*}$ & $0.3(0.2 ; 0.5)^{\star}$ & $0.4(0.2 ; 0.6)^{*}$ \\
\hline IL-6, pg/L & $2.0(0.0 ; 4.0)$ & $37.8(19.3 ; 41.3)^{*}$ & $38.2(17.5 ; 50.0)^{*}$ & $43.3(20.0 ; 62.3)^{*}$ \\
\hline IFN-y, pg/L & $9.4(0.0 ; 15.0)$ & $14.1(8.9 ; 18.6)^{\star *}$ & $37.6(18.3 ; 45.4)^{* / * *}$ & $13.5(8.2 ; 17.5)$ \\
\hline TNF- $\alpha, p g / L$ & $0.5(0.0 ; 2.0)$ & $2.2(1.3 ; 3.6)^{*}$ & $5.3(2.9 ; 7.4)^{* / * *}$ & $0.05(0.0 ; 0.08)^{* / * * * / * * * *}$ \\
\hline IL-4, pg/L & $0.2(0.0 ; 0.3)$ & $1.2(0.9 ; 1.9)^{\star / * *}$ & $0.4(0.2 ; 0.6)^{\star / * \star}$ & $0.5(0.1 ; 0.9)^{*}$ \\
\hline IL-10, pg/L & $4.5(0.2 ; 9.5)$ & $27.8(13.9 ; 38.6)^{\star / * *}$ & $19.2(11.2 ; 24.6)^{\star / * *}$ & $11.5(5.5 ; 18.5)^{*}$ \\
\hline VEGF, pg/L & $170.0(40.0 ; 280.0)$ & $217.3(90.2 ; 479.3)$ & $270.0(113.4 ; 532.0)$ & $328.0(296.5 ; 927.0)^{\star / * * / * \star * *}$ \\
\hline
\end{tabular}

*: differences in comparison with the reference values are significant $(P<0.05)$; **: significance of difference between groups I and II $(P<0.05)$; ***: significance of difference between groups III and I ( $<<0.05) ; * * * *$ : significance of difference between groups III and II $(\mathrm{P}<0.05)$.

Table 3. Content of $T$ lymphocyte subpopulations in patients with hepatosplenomegaly of different etiology $\left(\mathrm{Me}, \mathrm{Q}_{25} ; \mathrm{Q}_{75}\right)$

\begin{tabular}{|c|c|c|c|c|}
\hline \multirow{2}{*}{$\begin{array}{l}\text { T lymphocyte subpopulations, } \\
\text { units }\end{array}$} & \multirow{2}{*}{$\begin{array}{l}\text { Reference values, } \\
\mathrm{n}=38\end{array}$} & \multicolumn{3}{|l|}{ Studied groups } \\
\hline & & Group I (HCV/HBV), n = 32 & Group II (CMV/VEB), $\mathrm{n}=32$ & Group III (storage diseases), $n=9$ \\
\hline $\mathrm{T}$ helper, $\mathrm{CD}^{+}{ }^{+} \mathrm{CD} 4^{+}, \%$ & $41.0(32.0 ; 48.0)$ & $38.0(27.3 ; 43.5)^{\star \star}$ & $51.0(35.7 ; 66.4)^{* / * *}$ & $48.4(33.1 ; 56.7)$ \\
\hline $\begin{array}{l}\text { Co-stimulatory molecules } \\
\mathrm{CD}^{+} \mathrm{CD} 4^{+} \mathrm{CD} 28^{+}, \%\end{array}$ & $56.0(48.7 ; 62.0)$ & $30.1(20.2 ; 43.8)^{\star}$ & $36.7(28,4 ; 46.6)^{\star}$ & $27.8(22.4 ; 38.2)^{*}$ \\
\hline $\begin{array}{l}\text { Activated T lymphocytes, } \\
\text { CD } 3^{+} \mathrm{CD} 4^{+} \mathrm{CD} 25^{+}, \%\end{array}$ & $3.5(3.0 ; 4.5)$ & $1.5(0.4 ; 3.1)^{\star / * *}$ & $2.6(1.6 ; 2.9)^{\star \star}$ & $4.6(3.0 ; 5.8)$ \\
\hline $\begin{array}{l}\text { Regulatory T lymphocytes, } \\
\mathrm{CD} 3^{+} \mathrm{CD} 4^{+} \mathrm{CD} 25^{+} \mathrm{CD} 127^{\text {neg }}, \%\end{array}$ & $4.5(3.2 ; 5.4)$ & $1.9(1.5 ; 2.3)^{\star} / * *$ & $2.3(1.1 ; 3.0)^{\star * *}$ & $4.3(3.5 ; 6.0)$ \\
\hline $\begin{array}{l}\text { Late activation T lymphocytes marker } \\
\text { CD3 }{ }^{+} \mathrm{HLA}^{-} \mathrm{DR}^{+}, \%\end{array}$ & $8.0(5.5 ; 14.2)$ & $13.0(11.1 ; 20.7)^{\star / * *}$ & $3.5(3.0 ; 4.6)^{\star / \star \star}$ & $4.4(3.8 ; 6.1)^{*}$ \\
\hline
\end{tabular}

*: differences in comparison with the reference values are significant $(P<0.05)$; **: significance of difference between groups I and II $(P<0.05)$.

The content of B lymphocytes expressing CD22+ was reduced in patients with cirrhosis of the liver against the background of viral hepatitis (group I). And in groups II and III, the level of CD22+ $B$ lymphocytes was increased relative to the reference values (Fig. 1).

To form an adequate immune response to an antigen with subsequent elimination from the body, it is important to activate the lymphocytes of $T$ helper population $\mathrm{CD}^{+} \mathrm{CD} 4^{+}$. The population of $\mathrm{T}$ helpers was reduced in group I (patients with hepatitis B or/and C viruses) (Table 3).

The expression of co-stimulatory molecules $\mathrm{CD}^{+} \mathrm{CD} 4^{+} \mathrm{CD} 28^{+}$was reduced in group I ( $\mathrm{HCV} / \mathrm{HBV}$ ) by $46 \%$, in group II (CMV/VEB) - by $34 \%$. The most pronounced deficiency of co-stimulatory molecules (2-fold decrease) was revealed in patients with hepatosplenomegaly against the background of hereditary enzymopathies in group III (Fig. 2).

The number of activated $\mathrm{T}$ cells $\mathrm{CD} 3^{+} \mathrm{CD} 4^{+} \mathrm{CD} 25^{+}$was reduced in patients with hepatosplenomegaly of groups I and II - by 2.3 and 2 times, respectively, and in group III an increase in the number of activated Thelpers by 1.2 times was revealed (Table 3 ). The level of Treg (regulatory $\mathrm{T}$ cells) $\mathrm{CD} 3^{+} \mathrm{CD} 4^{+} \mathrm{CD} 25^{+} \mathrm{CD} 127^{\text {neg }}$ (producers of IL-10)

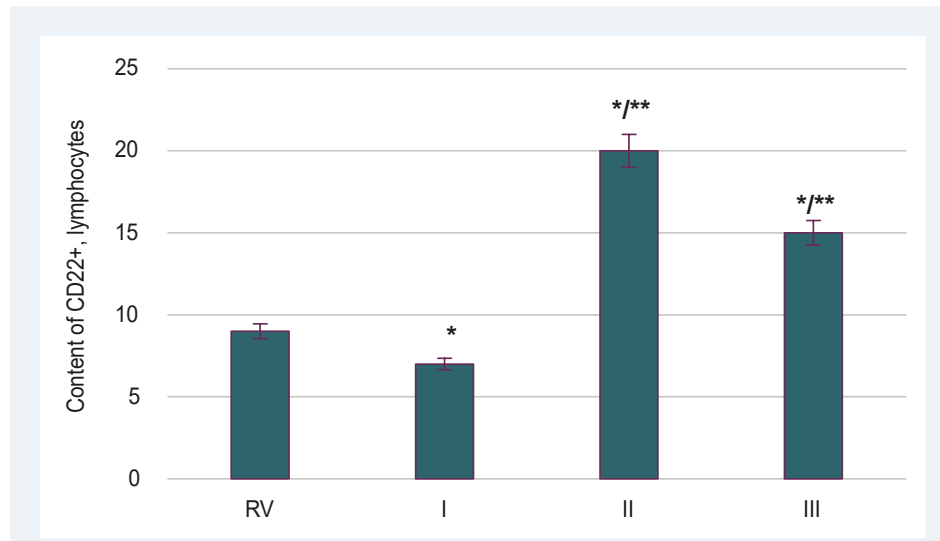

Fig. 1. Content of a subpopulation of $C D 22^{+} B$ lymphocytes in patients with hepatosplenomegaly.

*: differences in comparison with the reference values $(R V)$ are significant $(P<0.05)$ **: significance of difference between groups I and II $(P<0.05)$.

was decreased in groups I and II relative to the reference values (Table 3).

Multidirectional changes in the expression on $T$ cells of the class II HLA-DR receptor involved in signal transduction by activated $\mathrm{T}$ lymphocytes have revealed. 
$2 A$

[A] FL4Log/FL1 Log - ADC

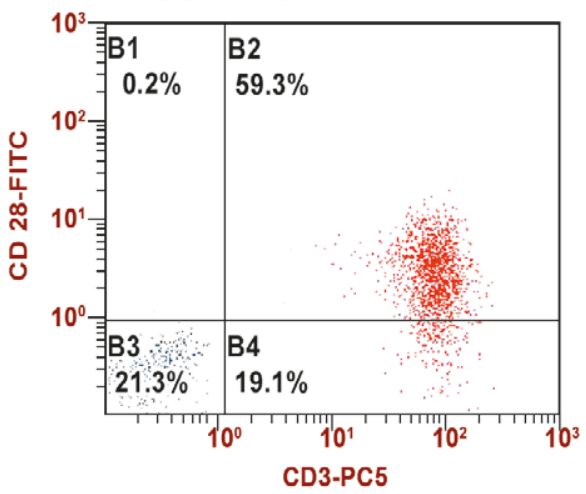

2C

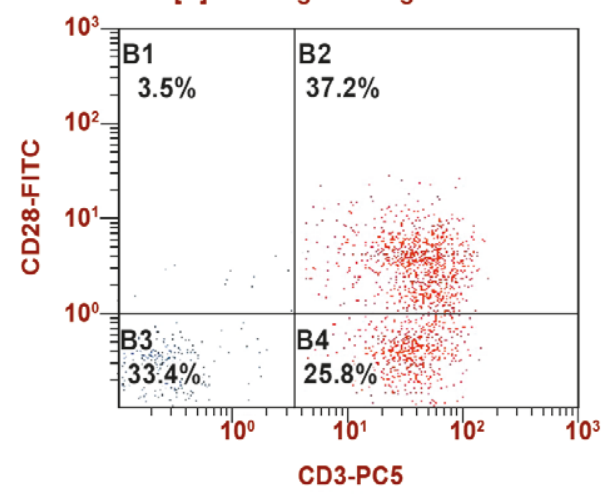

\section{A}

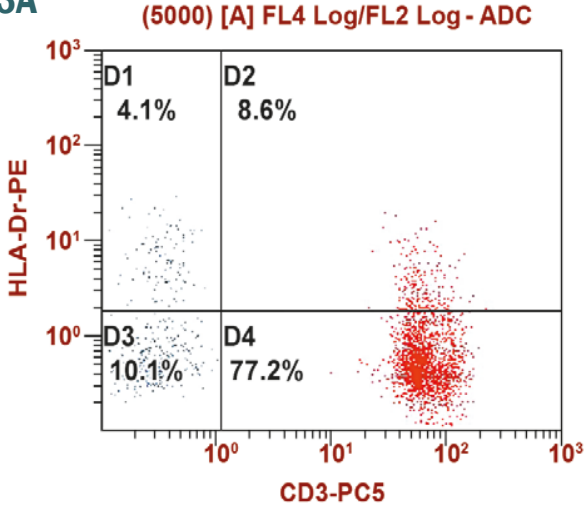

$3 \mathrm{C}$

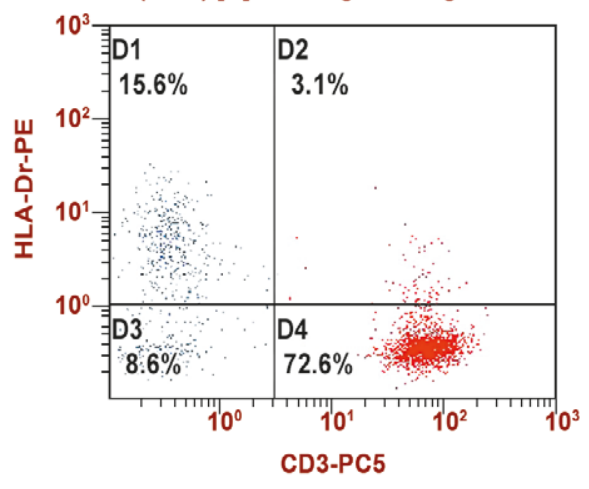

2B

[A] FL4 Log/FL1 Log - ADC

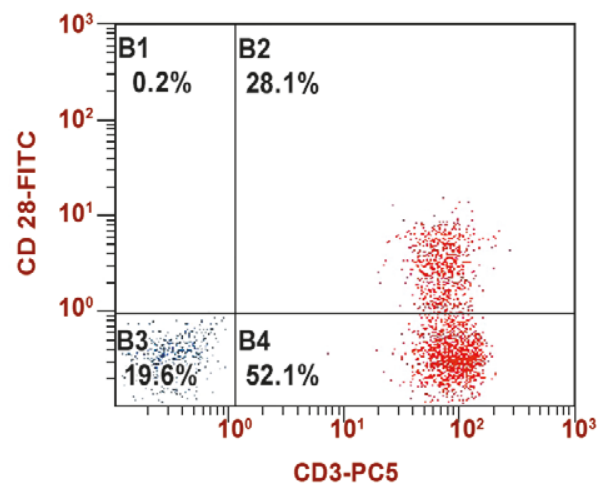

2D

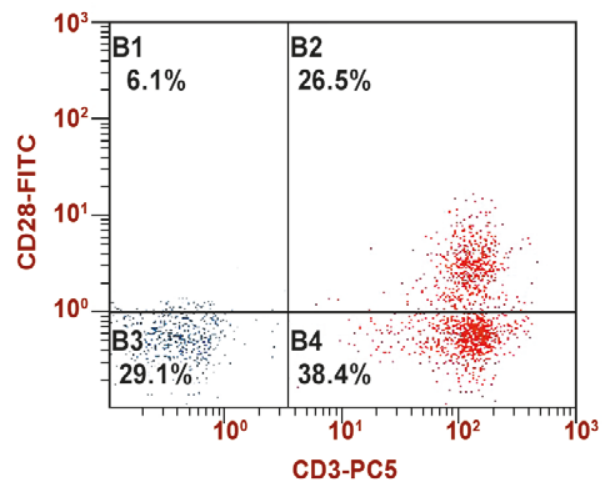

3B

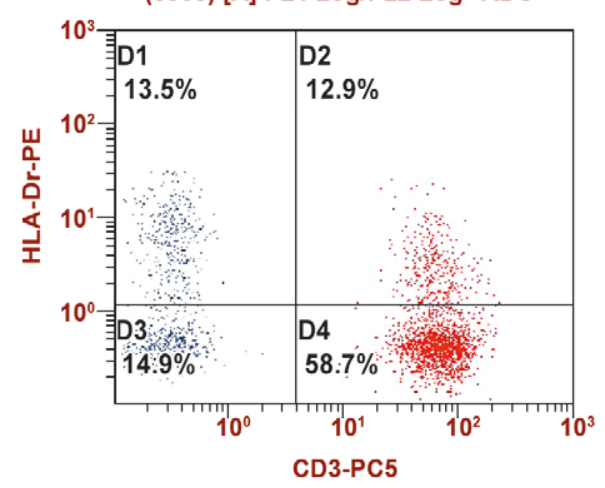

3D

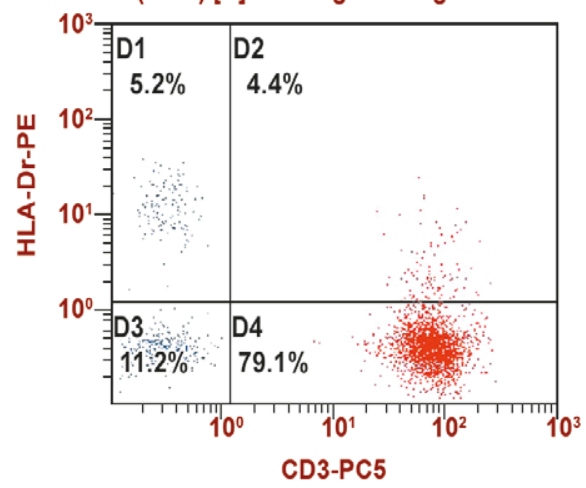

Fig. 2. Individual values of the relative amount of co-stimulatory molecules (CD3 ${ }^{+} \mathrm{CD} 4{ }^{+} \mathrm{CD} 28^{+}$lymphocytes): in a healthy donor (A), in a patient with hepatosplenomegaly on the background of HBV/HCV (B), CMVIVEB (C), in a patient with hereditary enzymopathies (D).
Fig. 3. Individual values of the relative amount of the late activation marker of lymphocytes (CD3 $\left.{ }^{+} \mathrm{HLA}-\mathrm{DR}^{+}\right)$: in a healthy donor (A), in a patient with hepatosplenomegaly on the background of $\mathrm{HBV} / \mathrm{HCV}$ (B), CMVIVEB (C), in a patient with hereditary enzymopathies (D). 
In patients with hepatitis viruses $\mathrm{HCV} / \mathrm{HBV}$, an increase in the expression of the late activation marker of lymphocytes $\mathrm{CD}^{+} \mathrm{HLA}^{-D R^{+}}$by an average of $63 \%$ was noted (Fig. 3). In patients with the herpesvirus CMVNEB (group II) and in patients with hereditary enzymopathies (group III) a decrease in the expression of $\mathrm{CD}^{+} \mathrm{HLA}-\mathrm{DR} \mathrm{R}^{+}$by $56 \%$ and $45 \%$, respectively, was revealed (Fig. 3).

\section{Discussion}

The involvement of the spleen in the pathogenesis of liver cirrhosis is due to the anatomical participation of both organs in the portal circulation, blood filtration, antigens and toxins elimination. The spleen, as a lymphoid organ of the immune system, is involved in pathological processes occurring in the liver when the immune response is impaired [6]. An increase in the size of the spleen can be a consequence of infection of the body and a violation of immunological protection certain links, with the subsequent formation of autoimmune processes or against the background of genetically determined metabolic disorders.

We have previously shown that the etiological factors of liver cirrhosis in patients with hepatosplenomegaly complicated by portal hypertension and recurrent bleeding are hepatitis $B$ viruses (HBV), hepatitis $C$ viruses (HCV), herpes viruses - cytomegalovirus (CMV), Epstein-Barr virus (VEB), Helicobacter pylori infection, toxoplasmosis (the causal agent of Toxoplasma gondii), and various genetic defects of lysosomal enzymes (storage diseases) $[7,8]$. The presence of certain trigger factors leads to the induction of specific mechanisms of the pathological process, which differ in the features of biochemical, immunological, hemostatic reactions [9].

The study of indexes of the immunity humoral link in patients with hepatosplenomegaly indicates an imbalance in the content of different classes of immunoglobulins depending on etiological factors. In particular, in group I a significant increase in IgA concentration was revealed with a normal content of antibody-producing $\mathrm{CD} 22^{+} \mathrm{B}$ lymphocytes. This phenomenon can be explained by a violation of the antigens elimination of the intestinal microflora due to insufficiency of liver function caused by viral cytolysis of hepatocytes. Antigens of the intestinal microbiota entering the systemic circulation through the portosystemic anastomoses of the affected liver induce the production of antibodies mainly in the spleen. In addition, IgA which is found in large quantities in the intestinal mucosa can enter the bloodstream through portosystemic anastomoses [10]. It can also be assumed that the high concentration of IgA is a consequence of the activation of $\mathrm{CD} 5^{+} \mathrm{B} 1$ lymphocytes subpopulation, which in the abdominal cavity can respond to both $\mathrm{T}$ dependent and $\mathrm{T}$ independent antigens [11].

In contrast to group I, in group II the increase in the concentration of IgA was less significant. We detected a high content of $\mathrm{IgM}$ as a marker of an acute infectious process against a background of $35 \%$ increased expression of the $\mathrm{CD} 22^{+}$marker on $\mathrm{B}$ lymphocytes. This indicates that in the group with autoimmune liver damage, the mechanism of lgM increase is associated with the reactivation of viral infection and chronic infection induced an increase in the synthesis of antiviral lgM. In addition, the increased content of antibody-producing $C D 22^{+} B$ lymphocytes in patients with herpesvirus etiology of autoimmune hepatitis (group II) may be the result of VEB reactivation which is known to enhance the proliferation of $B$ lymphocytes [12]. Reinfection or reactivation of lysogenic forms of CMV and/or VEB in the spleen induces antibody production by $B$ lymphocytes against the background of our revealed sharply reduced suppressive activity of $C D 8^{+}$ T lymphocytes in this group, which stimulated inflammatory reactions in these organs $[11,13]$.

The inflammatory process is initiated and mediated by the participation of a wide range of cytokines, which are capable of exerting both protective and damaging effects. But at the final stage of chronic diseases the increased level of various functional classes of cytokines is mainly associated with their damaging effects, such as the maintenance of local and systemic inflammation, apoptotic death of hepatocytes, progression of fibrosis and the development of extrahepatic complications [14].

An increased serum content of pro-inflammatory cytokines in liver cirrhosis was revealed in groups I and II. A significant increase in the concentration of IL-6 in all groups indicates the development of an acute inflammatory reaction. In group I a low level of IL-1 $\beta$ against the background of a high concentration of IL- 6 indicates the resolution of an acute inflammatory reaction, since one of the main functions of IL- 6 is self-limitation of the inflammatory response by suppressing the production of TNF- $\alpha$ and IL-1 $\beta$, and stimulation synthesis of an antagonist of the IL-1 receptor and the soluble TNF-p55 receptor [15]. Through stimulating B lymphocytes, IL-6 induces the synthesis of immunoglobulins and also participates in the differentiation of cytotoxic T lymphocytes [16].

An increase in the synthesis of IL-10 was observed in all groups, but most pronounced in groups I and II. This led to a decrease in anti-infectious protection, the development of immunosuppression, disruption of reparative processes due to a shift in the balance towards Th2 [16]. The high production of IL-10 is probably associated with a high level of immunoglobulins in these groups and as a consequence a high immune complexes concentration which acting on macrophages induces the secretion of many cytokines, including IL-10.

We have shown the concentration of TNF- $\alpha$ increases by 5 and 10 times in patients with cirrhosis of the liver of viral HBV/HCV etiology (group I) and in patients with cirrhosis of the liver against the background of herpes infection (group II), respectively. Since this cytokine is involved not only in defense reactions but also in the processes of destruction and repair of tissues. So, this increase enhances the inflammatory process. In long-term chronic inflammation TNF- $\alpha$, that is one of the mediators of tissue damage and activation of fibrogenesis, which is also associated with the ability of TNF- $\alpha$ to induce fibroblast proliferation and collagen deposition. A high concentration of TNF- $\alpha$ entails chronic inflammation, destruction and contributes to the unfavorable course of the pathological process. An excessive increase in the production of TNF- $\alpha, I L-6$, IL-10 against the background of the T-cell link deficiency and activation of the humoral link immunity enhance the progressive nature of inflammation and liver tissue destruction [17]. This is most pronounced in I and II groups. 
It is known that hereditary defects of lysosomal enzymes (glucocerebrosidase, chitotriosidase, angiotensin converting enzyme, acid lipase, etc.) lead to pathological accumulation of metabolites in cells and hyperplasia of many organs, including the liver and spleen [18]. There is evidence Gaucher cells (lipid-filled macrophages) express the vascular endothelial growth factor (VEGF) in patients with storage diseases. This cytokine not only stimulates angiogenesis, but also promotes the attraction of monocytes, which may be the reason for the local accumulation of Gaucher cells in various organs [19]. In group III a significant increase in VEGF was revealed, which indicates the activation of neoangiogenesis in the liver, endothelial dysfunction and can serve as an indirect marker of liver fibrosis. The development of intrahepatic angiogenesis can be considered as a compensatory mechanism aimed at decompression of the portal system. At the same time, the newly formed vessels carrying blood bypassing the sinusoids are unable to provide oxygen and nutrients to the liver tissue, which leads to the portal hypertension progression in patients of group III.

The interaction of antigens with antigen-recognizing receptors is a signal for the activation of $\mathrm{T}$ lymphocytes $\left(\mathrm{CD}^{+}\right)$. This is manifested by the secretion of cytokines that enhance the processes of proliferation and differentiation of various subpopulations of T lymphocytes, B lymphocytes and macrophages [16]. We have shown the content of the total number of $\mathrm{CD}^{+} \mathrm{T}$ lymphocytes in all patients with hepatosplenomegaly was reduced [8]. A decrease in the number of $\mathrm{CD}^{+} \mathrm{T}$ lymphocytes in all patients with hepatosplenomegaly may be due to secondary immune deficiency. Its formation is probably due to the damaging effect of toxic metabolites in viral infection and a genetic defect of lysosomal enzymes against the background of impaired detoxification function of the liver. In group II longterm course of herpesvirus led to a pronounced decrease in $\mathrm{CD}^{+} \mathrm{T}$ suppressors [8]. It is known, viral infection is associated with anergy of $C D 8^{+} T$ suppressor cells [20].

According to various authors, $T$ regulatory cells $\left(\mathrm{CD}^{+} \mathrm{CD} 4^{+} \mathrm{CD} 25^{+} \mathrm{CD} 127^{\text {neg }}\right)$ inhibit the functional activity of virus-specific cytotoxic CD8 ${ }^{+} \mathrm{T}$ lymphocytes in hepatitis $[21,22]$. Therefore, it can be assumed they play a central role in the viral infection and may be the target of immunotherapy. In patients of group I a decrease in regulatory T lymphocytes $\mathrm{CD} 3^{+} \mathrm{CD} 4^{+} \mathrm{CD} 25^{+} \mathrm{CD} 127^{\text {neg }}$ was revealed while in group III (patients with hepatosplenomegaly of non-infectious etiology) the expression of Treg cells did not differ from the reference values. According to Mengshol (2010) galectin-9 produced by Kupffer liver cells contributes to the maintenance of the number of Treg cells $\mathrm{CD} 4^{+} \mathrm{CD} 25^{+} \mathrm{FoxP} 3^{+} \mathrm{CD} 127^{\text {low }}$. This leads to inhibition of the effects of $\mathrm{CD} 4^{+}$cells and contributes to apoptosis of cytotoxic T lymphocytes [23,24].

The development of a strong and prolonged $T$ cell response with the predominant synthesis of cytokines characteristic of Th1 T lymphocytes (IFN- $\mathrm{y}, \mathrm{IL}-2$ ) and also the activation of effector cytotoxic $\mathrm{CD} 8^{+}$lymphocytes can lead to the termination of the infectious process. But the previously identified suppression of the CD8 ${ }^{+}$ subpopulation of $\mathrm{T}$ killer cells in group II indicates a long-term course of the pathogen with the development of a chronic process [8]. In the case when as a result of the opposition of the virus the body fails to implement the antiviral strategy due to the activation of Th1 T lymphocytes, the balance of Th1/Th2 T lymphocytes shifts towards the Th2 subpopulation with the predominance of pro-inflammatory cytokines $[17,25]$. Thus, in group I activation of Th1-dependent reactions is noted while in group II simultaneous activation of both Th1 and Th2-dependent reactions is noted.

The interaction of CD28 co-stimulatory molecules on $\mathrm{T}$ lymphocytes with ligand $\mathrm{B} 7$ (CD80/CD86) on antigen-presenting cells increases the production of cytokines by $T$ cells by further stabilizing the mRNA of these molecules and enhancing the transcription of their genes. Horst et al. (2020) has shown that insufficient formation of the B7/CD28 complex leads to a low level of T lymphocyte cytokines production the development of anergy and therefore blocks the immune response [16]. All examined patients showed a decrease in the expression of co-stimulatory molecules $\mathrm{CD} 3^{+} \mathrm{CD} 4^{+} \mathrm{CD} 28^{+}$reflecting the activation of the immune system, participating in cell-cell interaction and determining $T$ helper-dependent antibody production.

According to R. Oba et al. the most severe forms of liver cirrhosis are characterized by insufficiency of the immunity cellular component manifested by a decrease in the level of cytotoxic T lymphocytes along with an increase in the HLA receptors class II expression [26]. We also found a similar tendency in patients with hepatosplenomegaly associated with viral hepatitis; however, in groups II and III the expression of $\mathrm{CD}^{+} \mathrm{HLA}-\mathrm{DR}^{+}$receptors was reduced.

Immune disorders in hepatosplenomegaly depending on the etiology can be characterized by both changes in immunoreactivity and immunoresistance. Therefore, approaches to the treatment of patients with hepatosplenomegaly must be in complex. It is necessary to take into account the triggering infectious factors that cause the formation of various immune responses which can be one of the elements of further destruction and remodeling of organs.

\section{Conclusions}

1. In the overwhelming number of patients with hepatosplenomegaly trigger infectious factors were detected: hepatitis form $B$ orland $C$ viruses (in $47 \%$ ), herpes virus - cytomegalovirus or/and Epstein-Barr virus (in $42 \%$ ) and a small number (in $11 \%$ ) were diagnosed with enzymopathies - quantitative disorders of lysosomal enzymes - glucocerebrosidase and chitotriosidase.

2. Activation of the immunity humoral link in response to infection was revealed in group I - a significant increase in the $\lg A$ and $\lg M$ concentration, while the number of $B$ lymphocytes was at the level of reference values. In group II antibody production for the herpes infection presence was more pronounced in lgM, while the number of B lymphocytes was 2 times increased.

3. In group II the concentration of IL-1 $\beta$ was many times higher to reference values and this induced the entire cascade of humoral and cellular sensitization. TNF-a concentration was increased tenfold in this group. In group III we revealed a maximum increase in IL-6 (22 times), which indicates the presence of a cytokine storm 
in patients of this group who were admitted to the clinic at the height of bleeding. Group III showed a significant increase in VEGF. This factor stimulates angiogenesis and is a chemoattractant of Gaucher cells and an additional factor of their accumulation in the spleen and liver.

4. The activity of regulatory cells $\mathrm{CD} 3^{+} \mathrm{CD} 4^{+} \mathrm{CD} 25^{+} \mathrm{CD}$ $127^{\text {neg }}$ (as producers of IL-10) manifested itself as a manifold increase in this anti-inflammatory cytokine in response to the presence of a cytokine storm.

5. An increase in $\mathrm{CD}^{+} \mathrm{CD} 4^{+}$was revealed in groups II and III. The number of co-stimulatory molecules $\mathrm{CD}^{+} \mathrm{CD} 4^{+} \mathrm{CD} 28^{+}$was reduced in all groups, which indicates a violation of intercellular signaling. The deficiency of these molecules was revealed in patients with hereditary enzymopathies (group III).

\section{Funding}

The study is funded as a part of scientific work in SI "Zaitsev V. T. Institute of General and Urgent Surgery of National Academy of Medical Sciences of Ukraine": "Investigation of immunopathological parameters in splenomegaly and hypersplenism to justify different treatments", state registration No. 0118U006665.

Conflicts of interest: authors have no conflict of interest to declare. Конфлікт інтересів: віАсутній.

НаАійшла Ао редакції / Received: 19.04.2021

Після Аоопрацювання / Revised: 07.07.2021

Прийнято АО Аруку / Accepted: 13.07.2021

\section{Information about authors:}

Klimova O. M., PhD, DSc, Professor, Head of Diagnostic Laboratory with Enzyme Immunoassay and Immunofluorescence Analysis, SI "Zaitsev V. T. Institute of General and Urgent surgery of NAMS of Ukraine", Kharkiv; Professor of the Department of Molecular Biology and Biotechnology, V. N. Karazin Kharkiv National University, Ukraine.

ORCID ID: 0000-0002-4007-6806

Kordon T. I., PhD, Senior Researcher, Diagnostic Laboratory with Enzyme Immunoassay and Immunofluorescence Analysis, SI "Zaitsev V. T. Institute of General and Urgent Surgery of NAMS of Ukraine", Kharkiv.

ORCID ID: 0000-0001-5813-3656

Sushkov S. V., MD, PhD, DSc, Professor, Deputy Director for Research, SI "Zaitsev V. T. Institute of General and Urgent Surgery of NAMS of Ukraine", Kharkiv.

ORCID ID: 0000-0002-6951-9789

Drozdova L. A., PhD, Senior Researcher, Diagnostic Laboratory with Enzyme Immunoassay and Immunofluorescence Analysis, SI "Zaitsev V. T. Institute of General and Urgent Surgery of NAMS of Ukraine", Kharkiv.

\section{ORCID ID: 0000-0001-9678-4046}

Lavinska 0. V., PhD, Senior Researcher, Diagnostic Laboratory with Enzyme Immunoassay and Immunofluorescence Analysis, SI "Zaitsev V. T. Institute of General and Urgent Surgery of NAMS of Ukraine", Kharkiv; Associate Professor of the Department of Molecular Biology and Biotechnology, V. N. Karazin Kharkiv National University, Ukraine.

ORCID ID: 0000-0001-7320-0925

Merezhko O. S., Junior Researcher, Diagnostic Laboratory with Enzyme Immunoassay and Immunofluorescence Analysis, SI "Zaitsev V. T. Institute of General and Urgent Surgery of NAMS of Ukraine", Kharkiv; Laboratory Assistant of the Department of Molecular Biology and Biotechnology, V. N. Karazin Kharkiv National University, Ukraine.

ORCID ID: 0000-0001-9855-1780
Bychenko K. O., Junior Researcher, Diagnostic Laboratory with Enzyme Immunoassay and Immunofluorescence Analysis, SI "Zaitsev V. T. Institute of General and Urgent surgery of NAMS of Ukraine", Kharkiv; Postgraduate Student of the Department of Molecular Biology and Biotechnology, V. N. Karazin Kharkiv National University, Ukraine.

ORCID ID: $\underline{0000-0001-7885-7715}$

\section{Відомості про авторів:}

Кмімова О. М., А-р біол. наук, професор, зав. Аіагностичної лабораторії з імуноферментним та імунофлуоресцентним аналізом, АУ «Інститут загальної та невідкладної хірургії імені В. Т. Зайцева НАМН України", м. Харків; професор каф. молекулярної біології та біотехнології, Харківський національний університет імені В. Н. Каразіна, Україна. КорАон Т. І., канА. біол. наук, старший науковий співробітник, Аіагностична лабораторія з імуноферментним та імунофлуоресцентним аналізом, $A$ ॥ «нститут загальної та невіАкладної хірургї імені В. Т. Зайцева НАМН України", м. Харків.

Сушков С. В., А-р меА. наук, професор, заступник Аиректора 3 наукової роботи, АУ «Інститут загальної та невіАкладної хірургії імені В. Т. Зайцева НАМН України", м. Харків.

Ароздова ^. А., канА. біол. наук, старший науковий співробітник, Аіагностична лабораторія з імуноферментним та імунофлуоресцентним аналізом, АУ «Інститут загальної та невідкладної хірургії імені В. Т. Зайцева НАМН України", м. Харків.

Аавінська О. В., канА. біол. наук, старший науковий співробітник, Аіагностична лабораторія з імуноферментним та імунофмуоресцентним аналізом, АУ «Інститут загальної та невіАкладної хірургії імені В. Т. Зайцева НАМН України", м. Харків; доцент каф. молекулярної біології та біотехнології, Харківський національний університет імені В. Н. Каразіна, Україна.

Мережко О. С., молоАший науковий співробітник, Аіагностична лабораторія з імуноферментним та імунофмуоресцентним аналізом, АУ "Інститут загальної та невідкладної хірургї імені В. Т. Зайцева НАМН України", м. Харків; лаборант каф. молекулярної біології та біотехнології, Харківський національний університет імені В. Н. Каразіна, Україна.

Биченко К. О., молоАший науковий співробітник, Аіагностична лабораторія з імуноферментним та імунофлуоресцентним аналізом, АУ «нститут загальної та невіАкладної хірургї імені В. Т. Зайцева НАМН України", м. Харків, аспірант каф. молекулярної біології та біотехнології, Харківський національний університет імені В. Н. Каразіна, Україна.

\section{Сведения об авторах:}

Климова Е. М., А-р биол. наук, профессор,

зав. диагностической лабораторией с иммуноферментным и иммунофлуоресцентным анализом, ГУ «Институт общей и неотложной хирургии имени В. Т. Зайцева НАМН Украины", г. Харьков; профессор каф. молекулярной биологии и биотехнологии, Харьковский национальный университет имени В. Н. Каразина, Украина.

КорАон Т. И., канА. биол. наук, старший научный сотрудник, Аиагностическая лаборатория с иммуноферментным и иммунофлуоресцентным анализом, ГУ «Институт общей и неотложной хирургии имени В. Т. Зайцева НАМН Украины", г. Харьков. Сушков С. В., А-р меА. наук, профессор, заместитель Аиректора по научной работе, ГУ «Институт общей и неотложной хирургии имени В. Т. Зайцева НАМН Украины", г. Харьков.

АрозАова ^. А., канА. биол. наук, старший научный сотрудник, Аиагностическая каборатория с иммуноферментным и иммунофмуоресцентным анализом, ГУ “Институт общей и неотложной хирургии имени В. Т. Зайцева НАМН Украины", г. Харьков.

^авинская Е. В., канА. биол. наук, старший научный сотрудник, Аиагностическая лаборатория с иммуноферментным и иммунофлуоресцентным анализом, ГУ «Институт общей и неотложной хирургии имени В. Т. Зайцева НАМН Украины", г. Харьков; Аоцент каф. молекулярной биологии и биотехнологии, Харьковский национальный университет имени В. Н. Каразина, Украина. 
Мережко О. С., млаАший научный сотрудник, Аиагностическая лаборатория с иммуноферментным и иммунофлуоресцентным анализом, ГУ “Институт общей и неотложной хирургии имени В. Т. Зайцева НАМН Украины", г. Харьков; каборант каф. молекулярной биологии и биотехнологии, Харьковский национальный университет имени В. Н. Каразина, Украина. Быченко Е. А., младший научный сотрудник, Аиагностическая ^аборатория с иммуноферментным и иммунофлуоресцентным анализом, ГУ “Институт общей и неотложной хирургии имени В. Т. Зайцева НАМН Украины", г. Харьков; аспирант каф. молекулярной биологии и биотехнологии, Харьковский национальный университет имени В. Н. Каразина, Украина

\section{References}

[1] Albillos, A., Lario, M., \& Alvarez-Mon, M. (2014). Cirrhosis-associated immune dysfunction: Distinctive features and clinical relevance. Journal of hepatology, 61, 1385-1396. https://doi.org/10.1016/j. ihep.2014.08.010

[2] Hu, X., Huang, X., Hou, J., Ding, L., Su, C., \& Meng, F. (2020). Diagnostic accuracy of spleen stiffness to evaluate portal hypertension and esophageal varices in chronic liver disease: a systematic review and meta-analysis. European Radiology, 31, 2392-2404. https://doi. org/10.1007/s00330-020-07223-8

[3] Dinarello, C. A. (2018). Overview of the IL-1 family in innate inflammation and acquired immunity. Immunology Review, 281(1), 8-27. https:// doi.org/10.1111/imr.12621

[4] Engelmann, C., Sheikh, M., Sharma, S., Gupta, S., Andreola, F., \& Jalan, R. (2020). Toll-like receptor 4 is a therapeutic target for prevention and treatment of liver failure. Journal of hepatology, 73(1), 102-112. https://doi.org/10.1016/j.jhep.2020.01.011

[5] Ciesielcka, A., Matyjek, M., \& Kwiatkowska, K. (2021). TLR4 and CD14 trafficking and its influence on LPS-induced pro-inflammatory signaling. Cellular and molecular life sciences, 78, 1233-1261. https:// doi.org/10.1007/s00018-020-03656-y

[6] Li, L., Duan, M., Chen, W., Jiang, A., Li, X., Yang, J., \& Li, Z. (2017). The spleen in liver cirrhosis: revisiting an old enemy with novel targets. Journal of translational medicine, 15(1), 111. https://doi.org/10.1186/ $\underline{\text { s12967-017-1214-8 }}$

[7] Klimova, O. M., Sushkov, S. V., Timcenko, M. E., Riabcev, R. S., Kordon, T. I., Bychenko, E. A., \& Merezhko, O. S. (2019). Immunoreactivity changes in patients with gastrointestinal pathology against the background of chronic Helicobacter pylori infection. Surgery (Azerbaijan Republic), (4), 29-37.

[8] Klimova, O., Kordon, T., Smachylo, R., Belozorovl., Bychenko, E., Merezhko, O., \& Kudrevych, O. (2019). Dyferentsialna diahnostyka i korektsiia metabolichnykh ta imunolohichnykh porushen u khvorykh z tsyrozom pechinky, uskladnenym hepatosplenomehaliieiu ta portalnoiu hipertenziieiu [Differential diagnostics and correction of metabolic and immunological disorders in patients with hepatic cirrhosis, complicated hepatosplenomegalia and portal hypertension]. Actual Problems of Modern Medicine, (4), 31-41. [in Ukrainian]. https://doi. org/10.26565/2617-409X-2019-4-04

[9] Klimova, E. M., Kalashnikova, Y. V., Kordon, T. I., Lavinskaya, E. V., Agarkova, A. N., Osmanov, R. R., \& Ryabinskaya, O. V. (2020). Prediktory gemorragicheskikh i tromboticheskikh oslozhnenii sindroma gepatosplenomegalii [Predictors of hemorrhagic and thrombotic complications of hepatosplenomegaly syndrome]. Kharkiv Surgical School, (1) 148-154. [in Russian]. https://doi.org/10.37699/2308-7005.1.2020.25

[10] Inamine, T., \& Schnabl, B. (2018). Immunoglobulin A and liver diseases. Journal of gastroenterology, 53(6), 691-700. https://doi.org/10.1007/ s00535-017-1400-8

[11] Takada, D., Sumida, K., Sekine, A., Hazue, R., Yamanouchi, M., Suwabe, T., Hayami, N., Hoshino, J., Sawa, N., Takaichi, K., Fujii, T., Ohachi, K., \& Ubara, Y. (2017). IgA nephropathy featuring massive wire loop-like deposits in two patients with alcoholic cirrhosis. BMC Nephrology, 18(1), 362. https://doi.org/10.1186/s12882-017-0769-1

[12] Oliveira, F. L., Bernardes, E. S., Brand, C., dos Santos, S. N., Cabanel, M. P., Arcanjo, K. D., Brito, J. M., Borojevic, R., Chammas, R., \& El-Cheikh, M. C. (2016). Lack of galectin-3 up-regulates IgA expression by peritoneal B1 lymphocytes during B cell differentiation. Cell and tissue research, 363(2), 411-426. https://doi.org/10.1007/ s00441-015-2203-y

[13] Taylor, S. A., Assis, D. N., \& Mack, C. L. (2019). The Contribution of B Cells in Autoimmune Liver Diseases. Seminars in Liver Disease, 39(4), 422-431. https://doi.org/10.1055/s-0039-1688751

[14] Kawaratani, H., Tsujimoto, T., Douhara, A., Takaya, H., Moriya, K., Namisaki, T., Noguchi, R., Yoshiji, H., Fujimoto, M., \& Fukui, H. (2013). The effect of inflammatory cytokines in alcoholic liver disease. Mediators of Inflammation, 2013, 495156. https://doi.org/10.1155/2013/495156
[15] Topolyanskaya, S. V. (2020). Rol' interlejkina 6 pri starenii i vozrast associirovannyh zabolevanijah [Interleukin 6 in aging and age-related diseases]. Klinitsist, 14(3-4), 10-17. [in Russian]

[16] Horst, A. K., Kumashie, K. G., Neumann, K., Diehl, L., \& Tiegs, G. (2021) Antigen presentation, autoantibody production, and therapeutic targets in autoimmune liver disease. Cellular \& molecular immunology, 18(1), 92-111. https://doi.org/10.1038/s41423-020-00568-6

[17] Pinto, C., Giordano, D. M., Maroni, L., \& Marzioni, M. (2018). Role of inflammation and proinflammatory cytokines in cholangiocyte pathophysiology. Biochimica et biophysica acta. Molecular basis of disease, 1864(4 Pt B), 1270-1278. https://doi.org/10.1016/j.bbadis.2017.07.024

[18] Ferreira, C. R, \& Gahl, W. A. (2017). Lysosomal storage diseases. Translational Scince of rare disease, 2(1-2), 1-71. https://doi. org/10.3233/TRD-160005

[19] Ivanova, M., Limgala, R. P., Changsila, E., Kamath, R., loanou, C., \& Goker-Alpan, O. (2018). Gaucheromas: When macrophages promote tumor formation and dissemination. Blood cells, molecules \& diseases, 68, 100-105. https://doi.org/10.1016/j.bcmd.2016.10.018

[20] Karkhad, A., Javanian, M., \& Ebrahimpour, S. (2018). The role of regulatory $T$ cells in immunopathogenesis and immunotherapy of viral infections. Infection, Genetics and Evolution, 59, 32-37. https://doi. org/10.1016/j.meegid.2018.01.015

[21] Dominguez-Villar, M., \& Hafler, D. A. (2018). Regulatory T cells in autoimmune disease. Nature Immunology, 19(7), 665-673. https://doi. org/10.1038/s41590-018-0120-4

[22] Van der Heide, D., Weiskirchen, R., \& Bansal, R. (2019). Therapeutic Targeting of Hepatic Macrophages for the Treatment of Liver Diseases. Frontiers in immunology, 10, 2852. https://doi.org/10.3389/ fimmu.2019.02852

[23] Liberal, R., Grant, C. R., Longhi, M. S., Mieli-Vergani, G., \& Vergani, D. (2015). Regulatory T cells: Mechanisms of suppression and impairment in autoimmune liver disease. IUBMB life, 67(2), 88-97. https://doi.org/10.1002/iub.1349

[24] Burghardt, S., Claass, B., Erhardt, A., Karimi, K., \& Tiegs, G. (2014). Hepatocytes induce Foxp $3^{+}$regulatory $T$ cells by Notch signaling. Journal of leukocyte biology, 96(4), 571-577. https://doi.org/10.1189/ ilb.2AB0613-342RR

[25] Robinson, M. W., Harmon, C., \& O'Farrelly, C. (2016). Liver immunology and its role in inflammation and homeostasis. Cellular \& molecular immunology, 13(3), 267-276. https://doi.org/10.1038/cmi.2016.3

[26] Oba, R., Isomura, M., Igarashi, A., \& Nagata, K. (2019). Circulating

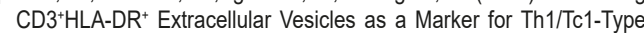
Immune Responses. Journal of immunology research, 2019, 6720819. https://doi.org/10.1155/2019/6720819 